\title{
Pemberdayaan Masyarakat Pesisir Pondok Mimbo Dalam Upaya Meningkatkan Kesadaran Administrasi Kependudukan Dan Kemandirian Nelayan
}

\section{Empowerment of Pondok Mimbo Coastal Communities in an Effort to Increase Awareness of Population Administration and Fisherman Independence}

\author{
Erna Agustina ${ }^{1}$, Dimas Imaniar $^{1^{*}}$ \\ ${ }^{1}$ Dosen FISIP Universitas 17 Agustus 1945 Banyuwangi \\ Corresponding author: dimasimaniars@gmail.com
}

Submited: 26 June 2021 Revised: 08 July 2021 Accepted: 22 July 2021

Publish: 31 July 2021

\begin{abstract}
Abstrak
Dusun Pondok Mimbo Desa Sumberanyar merupakan salah satu kampung nelayan terbesar di Kabupaten Situbondo setelah Desa Kilensari Kecamatan Panarukan. Masyarakat pondok mimbo sebagian besar adalah masyarakat pribumi yang silsilahnya berasal dari Madura Jawa Timur. Desa pondok Mimbo merupakan kawasan andalan Kabupaten Situbondo yang mempunyai peranan penting dalam mewujudkan Kabupaten Situbondo sebagai kawasan bahari di pesisir utara pulau Jawa. Penelitian ini menemukan model pemberdayaan yang tepat bagi masyarakat pesisir Pondok Mimbo dan menganalisis upaya peningkatan kesadaran administrasi kependudukan dan kemandirian nelayan Pondok Mimbo. Penelitian ini termasuk dalam penelitian deskriptif kualitatif dengan pendekatan sosiologis, atau dalam penelitian administrasi publik biasa disebut normatif terapan/normatif empiris. Model pemberdayaan yang bertujuan membangun kemandirian nelayan Pondok Mimbo dapat dilaksanakan dengan kerjasama dan partisipasi masyarakat. Perlu sinergitas antara peran pemerintah baik aparat desa dan instansi terkait lainnya, LSM yang peduli atau pun perusahaan, kampus maupun masyarakat nelayan itu sendiri. Terdapat faktor pendukung dan faktor penghambat yang harus diperhatikan dan dicarikan solusinya. Faktor pendukung antara lain sudah terbangun konsep kesadaran dalam melakukan segala macam kegiatan yang sesuai dengan administrasi kependudukan yang ada, potensi wisata dan produksi perikanan, aparat Desa yang cukup aktif dan kesiapan SDM untuk memotivasi diri dan menerima pendampingan serta berbagai pelatihan. Adapun faktor penghambatnya antara lain: terbatasnya modal, faktor alam, sarana prasarana, kurangnya gairah wisata, daya minat beli dan daya minat permainan air, tidak adanya penghasillan rutin, honor pekerja yang kurang dari UMK, SDM, dan kurangnya kesadaran administrasi kependudukan, bantuan hukum dan perlindungan hukum.

Kata kunci: pemberdayaan, kesadaran, kemandirian nelayan.
\end{abstract}

\section{Abstract}

Pondok Mimbo, Sumberanyar Village is one of the largest fishing villages in Situbondo Regency after Kilensari Village, Panarukan District. The people of Pondok Mimbo are mostly indigenous people whose lineage comes from Madura, East Java. Pondok Mimbo Village is a mainstay area of Situbondo Regency which has an important role in realizing Situbondo Regency as a marine area on the north coast of Java. This study finds the right empowerment model for the coastal community of Pondok Mimbo and analyzes efforts to increase awareness of population administration and the independence of fishermen in Pondok Mimbo. This research is included in descriptive qualitative research with a sociological approach, or in public administration research commonly referred to as applied normative/empirical normative. The empowerment model which aims to build the independence of the fishermen of Pondok Mimbo can be implemented with the cooperation and participation of the community. There needs to be a synergy between the role of the government, both village officials and other relevant agencies, NGOs or related companies, campuses, and the fishing communities themselves. There are supporting factors and inhibiting factors that must be considered and solutions are sought. Supporting factors include the development of the concept of awareness in carrying out all kinds of activities in accordance with the existing population administration, tourism potential and fishery production, active village officials, and the readiness of human resources to motivate themselves and receive assistance and various trainings. The inhibiting factors include limited capital, natural factors, infrastructure, lack of interest in tourism, purchasing power and interest in water games, non-routine income, workers' salaries that are less than the 
minimum wage, human resources, and lack of awareness of the population. administration, legal aid, and legal protection.

Keywords: empowerment, awareness, independence of fishermen.

\section{PENDAHULUAN}

Indonesia merupakan Negara

Kepulauan dengan jumlah pulau yang mencapai 17.508 dan panjang garis pantai kurang lebih $81.000 \mathrm{Km}$. Keadaan ini menyebabkan kawasan pesisir menjadi andalan sumber pendapatan masyarakat Indonesia (Tinambunan, 2015). Sementara Indonesia, sebagai negara maritim, potensi sumberdaya kelautan, pesisir, dan pulau-pulau kecil sangatlah besar dan berlimpah untuk dikelola secara optimal sehingga bisa memberi dampak multidimensi yang signifikan bagi negara dan bangsa (Hariyanto, 2014). Pemberdayaan adalah suatu proses dan sekaligus hasil dari proses tersebut (Tampubolon, 2012).

Pemberdayaan adalah bagian dari paradigma pembangunan yang memfokuskan perhatiannya kepada semua aspek yang prinsipil dari manusia di lingkungannya yakni mulai dari aspek intelektual (SDM), aspek material dan fisik, sampai kepada aspek manajerial (Sutarto, 2018). Tujuan utama pemberdayaan menurut Suharto (2017) adalah "memperkuat kekuasaan masyarakat, khususnya kelompok lemah yang memiliki ketidakberdayaan, karena kondisi internal (seperti persepsi mereka sendiri), maupun karena kondisi eksternal (misalnya ditindas oleh struktur sosial yang tidak adil). Prinsip pemberdayaan terdiri dari kesetaraan, partisipatif, keswadayaan, dan berkelanjutan (Najiyati, Asmana, \& Suryadiputra, 2005). Pemberdayaan masyarakat di Indonesia telah menjadi program nasional pemerintah dan swasta (Ma'arif, 2016). Pemberdayaan masyarakat tidak lain adalah upaya penanggulangan kemiskinan dan keterbelakangan (Rahim, Tahir, \& Rumbia, 2014).

Pemberdayaan masyarakat bukan membuat masyarakat menjadi makin tergantung pada berbagai program pemberian (charity). Pendekatan utama dalam konsep pemberdayaan adalah masyarakat tidak dijadikan objek dari berbagai proyek pembangunan, tetapi merupakan subjek dari upaya pembangunan sendiri (Theresia, 2015). Pemberdayaan masyarakat pesisir haruslah bersifat bottom up dan open menu, namun yang terpenting adalah pemberdayaan itu 
sendiri yang harus langsung menyentuh kelompok masyarakat sasaran (Desmiyawati, Hasan, Samsir, \& Azlina, 2015). Pemberdayaan masyarakat pesisir seharusnya lebih diarahkan kepada pemberdayaan masyarakat terkait potensi yang dimiliki oleh desa itu sendiri. Sayangnya potensi yang demikian besar tersebut belum diberdayakan secara optimal, sehingga masyarakat pesisir di Indonesia masih berada dalam kondisi miskin, dengan kata lain masih belum sejahtera (Nuryanto \& Haryono, 2017).

Pemberdayaan bagi masyarakat pesisir dimaksudkan untuk meningkatkan ekonomi dan kesadaran administrasi mereka dengan memberikan pembekalan dan pengetahuan agar dapat lebih maksimal menggali potensi sumber daya alam yang tersedia. Dusun Pondok Mimbo Desa Sumberanyar Kecamatan Banyuputih merupakan salah satu Desa yang berada di Kecamatan Banyuputih Kabupaten Situbondo. Selain memiliki perairan laut yang cukup luas, desa ini juga memiliki potensi perikanan yang cukup besar bila dikelola dan dimanfaatkan dengan baik Potensi sumber daya laut yang cukup besar tidak diimbangi dengan kehidupan masyarakat pesisir di desa ini yang sebagian besar masyarakatnya belum sejahtera. Kondisi ini diperparah dengan banyaknya kebutuhan hidup yang dialami oleh masyarakat pesisir Dusun Pondok Mimbo seperti kehidupan sehari-hari, pendidikan dan kesehatan. Pemberdayaan masyarakat yang sudah dilakukan di Dusun Pondok Mimbo terhadap masyarakat pesisir antara lain: (1) Berupa pelaksanaan bantuan pembinaan pembuatan Keripik Kulit Ikan kepada Kelompok Makmur Jaya dimana kelompok ini beranggotakan 5 orang bermata pencaharain sebagai nelayan, 5 orang buruh dan 15 orang ibu rumah tangga; (2) pembinaan berupa budidaya Ikan Air Tawar kepada Kelompok Segara Arum yang beranggotakan 15 orang nelayan dan 10 orang buruh; (3) pembinaan berupa produk olahan Ikan Air Laut kepada Kelompok Mimbo Abadi yang beranggotakan 16 nelayan dan 9 orang buruh.

Pembangunan infrastruktur dan pertumbuhan ekonomi lebih banyak dinikmati oleh penduduk yang tinggal di daerah perkotaan daripada penduduk yang tinggal di wilayah pesisir (hinterland), sehingga cenderung terjadi kesenjangan antara penduduk di daerah 
perkotaan dengan penduduk di daerah pesisir. (Qodriyatun, 2013). Masyarakat pesisir dimaksudkan adalah masyarakat yang tinggal di daerah pesisir dan sumber kehidupan perekonomiannya bergantung secara langsung pada pemanfaatan sumberdaya laut dan pesisir melalui kegiatan penangkapan dan budidaya. (Rahmanto, 2015).

Masyarakat yang tinggal di wilayah pesisir pantai di Indonesia dikenal sebagai kawasan masyarakat miskin, kumuh dan terbelakang (Nugroho, 2015). Ekonomi masyarakat pesisir merupakan kegiatan pengelolaan sumberdaya pesisir dan masyarakat yang tinggal di wilayah tersebut (Witarsa, 2015). Di samping untuk meningkatkan kesejahteraan masyarakat nelayan, juga bertujuan untuk mendidikan agar nelayan lebih mandiri dan mempunyai kemampuan untuk hidup lebih baik dalam memanfaatkan sumber daya yang ada secara optimal dan berkelanjutan (Zamzami, 2011).

\section{Besarnya potensi kelautan} tersebut ternyata tidak diikuti oleh kesejahteraan masyarakat nelayan. Hal ini terlihat dimana kondisi sosial ekonomi nelayan kita sangat jauh berbeda dengan potensi sumberdaya alamnya (Razali, 2004). Iklim global yang semakin tidak menentu menyebabkan gelombang lautan sulit untuk diperkirakan, sehingga masyarakat pesisir yang berprofesi sebagai nelayan mengalami kendala dalam berlayar untuk menangkap ikan (Mulyatun, 2018). Uraian di atas, memberi arahan bahwanya perlu ada upaya lebih nyata dari pemerintah untuk mengoptimalkan potensi sumber daya kelautan dan fokus menyelesaikan masalah pokok dalam kemiskinan nelayan (Durianto, Suryono, \& Hermawan, 2014). Pengertian ekonomi secara utuh yaitu ilmu ekonomi adalah salah satu cabang ilmu pengetahun yang berdaya upaya untuk memberikan pengetahuan dan pengertian tentang gejala-gejala masyarakat yang timbul karena perbuatan manusia dalam usahanaya untuk memenuhi kebutuhannya atau untuk mencapai kemakmuran. Selanjutnya ia juga menyatakan "begitu banyak tujuan hidup seseorang akan tetapi satu hal yang pasti yaitu bahwa setiap orang tentu ingin memiliki pendapatan yang cukup yang akan memungkinkan untuk memilih cara hidup yang dipilih dan yang disukainya, semakin besar pendapataanya akan semakin luas 
kesempatan yang terbuka baginya untuk memenuhi keinginannya.

Ekonomi secara umum mengkaji mengenai pemenuhan kebutuhan manusia dan kemakmuran manusia, hal pokok permasalahan ekonomi tersebut yaitu kebutuhan dan pencapaian kemakmuran. Dua hal ini merupakan salah satu dasar sosial di dalam masyarakat bila dihubungkan dengan permasalahan mikro tingkat ekonomi, masyarakat, dengan kata lain semakin makmur seseorang dan semakin mampu untuk memenuhi kebutuhannya dengan berbagai tingkatanya maka semakin tinggi pula tingkat ekonomi seseorang didalam struktur sosial kemasayarakatan (Rosyidi, 2009).

\section{METODE PENELITIAN}

Penelitian ini merupakan penelitian deskriptif yang bertujuan untuk mendeskripsikan serta menganalisis pemberdayaan masyarakat pesisir dalam upaya meningkatkan ekonomi dan kesadaran administrasi di Dusun Pondok Mimbo, Kecamatan Banyuputih melalui program pemberdayaan; (1) Keripik Kulit Ikan Kelompok Makmur Jaya, (2) Budidaya Ikan Air Tawar kepada Kelompok Segara Arum, (3) Pembinaan berupa produk olahan Ikan Air Laut kepada Kelompok Mimbo Abadi. Subjek penelitian yaitu Kepala Dusun dan Masyarakat Pesisir di Dusun Pondok Mimbo Kecamatan Banyuputih. Objek dalam penelitian yaitu Pemberdayaan Masyarakat Pesisir Dalam Upaya Meningkatkan Ekonomi dan kesadaran administrasi di Dusun Pondok Mimbo, Kecamatan Banyuputih. Penentuan sampel penelitian dilakukan saat memasuki lapangan dan selama penelitian berlangsung dengan cara seorang peneliti memilih Kepala Dusun yang dipilih untuk memberikan data. Peneliti juga memilih sampel Masyarakat Pesisir yang diwawancarai berjumlah 6 orang dimana setiap 1 kelompok pemberdayaan dipilih 1 orang ketua kelompok dan 1 orang anggota untuk memberikan informasi secara jelas mengenai masing-masing program pemberdayaan agar memberikan tambahan data yang lebih lengkap. Teknik pengumpulan data yang digunakan berupa wawancara, observasi dan dokumentasi. Analisis data dilakukan dengan pengumpulan data, reduksi data, penyajian data dan penarikan kesimpulan.

HASIL DAN PEMBAHASAN 
Dusun Mimbo adalah salah satu dusun di Desa Sumberanyar Kecamatan Banyuputih, Kabupaten Situbondo. Dusun Mimbo berada di sebelah utara dan berbatasan dengan Selat Madura, wilayah tersebut memiliki potensi perairan yang baik. Dusun Mimbo yang berada di daerah pesisir rata-rata penduduk di dusun tersebut bermatapencaharian sebagai nelayan. Pada tahun 2000 penduduk Desa Sumberanyar berjumlah 13.848, dan pada tahun 2001 berjumlah 13.813.12 Pada tahun 2000 jumlah penduduk di Desa Sumberanyar semakin menurun yaitu 13.884, di sebabkan angka kematian bayi baru lahir sangat tinggi yaitu sekitar 21 bayi, dikarenakan pada saat itu perempuan yang melahirkan masih menggunakan dukun beranak, dengan peralatan bersalin yang sederhana, meskipun sudah ada puskesmas yang menangani persalinan akan tetapi mereka lebih percaya pada dukun beranak, dan terdapat 15 orang yang pindah ke daerah lain (ke luar Desa Sumberanyar), perpindahan ini disebabkan perkawinan. Sedangkan pada tahun 2001 jumlah penduduk semakin menurun dibandingkan dengan jumlah penduduk pada tahun 2000, hal ini disebabkan pada tahun 2001 masyarakat di Desa Sumberanyar sudah banyak yang mengikuti program KB (keluarga berencana), sehingga pertumbuhan penduduk semakin menurun.

Pondok Mimbo merupakan salah satu dusun yang berada di Desa Sumberanyar, dusun ini memiliki perairan laut yang cukup luas dan memiliki potensi perikanan yang cukup besar. Mayoritas masyarakatnya menggeluti profesi sebagai nelayan dan buruh. Sebagian besar masyarakat di dusun ini menggantungkan hidupnya dari hasil kegiatan melaut. Dusun Pondok Mimbo ini terdapat beberapa perahu bersandar, dimana perahu yang bersandar inilah yang menjadi alat utama untuk melaut. Mereka mencari ikan dilaut, yang jaraknya 1-2 km dari tempat tinggal mereka dengan menggunakan perahu yang mereka gunakan untuk bekerja. Nelayan biasanya mulai bekerja pada sore hari maka dari itu pemukiman nelayan biasanya sangat sepi, dikarenakan para nelayan beristirahat di rumah dan tidak ada yang melakukan pekerjaan pada siang hari selain itu ada juga nelayan yang berada di perahunya untuk sekedar mengecek keadaan perahu atau mengisi bahan bakar. Istri para nelayan ini 
keseharianya hanya menjadi ibu rumah tangga, selain dari itu ada juga yang bekerja di pasar, atau sebagai bakul ikan. Mereka hanya mengandalkan penghasilan dari suaminya sebagai nelayan.

Adanya program permberdayaan yang diberikan oleh pemerintahan desa bagi masyarakat pesisir dimaksudkan untuk meningkatkan ekonomi dan kesadaran administrasi mereka dengan memberikan pembekalan dan pengetahuan agar dapat lebih maksimal menggali potesi sumber daya alam yang tersedia. Pemberdayaan masyarakat pesisir di dusun ini menjadikan masyarakat pesisir sebagai rekan kerja bagi desa untuk melaksanakan programprogram pemberdayaan dan kesadaran administrasi, sehingga tujuan tersebut dapat terlaksana untuk memperbaiki taraf hidup atau kesejahteraan masyarakat pesisir sehingga dapat meningkatkan ekonomi dan kesadaran administrasi di Dusun Pondok Mimbo, Desa Sumberanyar, Kecamatan Banyuputih. Berdasarkan hasil penelitian tentang pemberdayaan masyarakat pesisir dalam upaya menigkatkan ekonomi dan kesadaran administrasi di Dusun Pondok Mimbo, Desa Sumberanyar, Kecamatan
Banyuputih pandangan dari masyarakat yang diberdayakan menjawab sangat setuju tentang adanya program pemberdayaan yang dilaksanakan di desa ini. Masyarakat pesisir sangat mendukung dengan adanya program pemberdayaan ini karena dapat memanfaatkan sumber daya alam yang berada di dusun ini dan dapat menggali potensi sumber daya manusia yang berada di Dusun Pondok Mimbo, Desa Sumberanyar, Kecamatan Banyuputih.

\section{PEMBAHASAN}

Program pemberdayaan yang pertama yaitu Pembinaan Pembuatan Keripik Kulit Ikan Kelompok Makmur Jaya. Pengolahan Keripik Kulit Ikan Gurami masih sangat sederhana, bahkan pengemasan produk dilakukan dengan cara yang masih tradisional, yakni hanya dalam kemasan plastik ulir dan diikat dengan tali tanpa adanya label kemasan kemudian dijual dengan harga eceran. Proses pengolahan yang dibutuhkan untuk dapat menjadi keripik siap makan dilakukan tahap yang cukup panjang, akan tetapi keuntungan yang didapat belum sebanding dengan proses yang dibutuhkan. Dalam proses pengolahan, hanya sebatas produk yang dapat dipasarkan di sekitar Desa saja dan cenderung memiliki nilai jual yang 
tidak terlalu tinggi. Program ini merajuk pada pendapat (Suharto, 2017) bahwa pemberdayaan merupakan proses dan tujuan sehingga perlu mendapat pendampingan untuk pengembangan produk dan dapat dirubah menjadi produk olahan keripik kulit ikan dengan daya jual yang tinggi sebagai pilihan oleh-oleh khas desa. Dapat mencapai tujuan untuk menambah penghasilan bagi masyarakat pesisir, namun desa hanya menjalankan program tanpa adanya arahan dan pendampingan yang signifikan serta pemasaran yang kurang efektif terhadap olahan dari produksi yang dibuat sehingga pendapatan masyarakat yang mengikuti program dari pemberdayaan ini masih sama dengan sebelumnya. Olahan yang di produksi menggunakan bahan pokok berupa ikan air tawar yang diolah agar bernilai jual tinggi.

Program pemberdayaan yang kedua yaitu Pembinaan Berupa Budidaya Ikan Air Tawar Kepada Kelompok Segara Arum, perlu mendapat pembinaan dari Desa serta Dinas Kelautan dan Perikanan agar pembudidaya lebih produktif sehingga saat panen mendapatkan hasil yang maksimal. Selain menjual secara mentah hasil panen keluar daerah, pembudidaya seharusnya bisa mengolah sendiri agar mendapatkan nilai jual yang lebih tinggi. Sehingga dapat menunjang pendapatan desa dan masyarakat pesisir di Dusun Pondok Mimbo, Desa Sumberanyar, Kecamatan Banyuputih. Program ini merajuk pada pendapat (Najiyati, S., dkk., 2005) tentang prinsip pemberdayaan salah satunya yaitu partisipatif yang artinya program pemberdayaan yang sifatnya direncanakan, dilaksanakan, diawasi, dan dievaluasi namun perlu proses pendampingan yang melibatkan pendamping yang berkomitmen tinggi terhadap pemberdayaan masyarakat. Selain membudidayakan ikan air tawar desa juga mengembangkan potensi budidaya ikan air laut.

Dapat dilihat program pemberdayaan yang ketiga yaitu Pembinaan Produk Olahan Ikan Air Laut kepada Kelompok Mimbo Abadi, kelompok usaha seharusnya mendapat pembinaan dari Desa serta Dinas Kelautan dan Perikanan, pemeliharan produk olahan ikan air laut khusunya ikan kerapu memerlukan perhatian yang cukup besar sehingga perlu direncanakan dengan matang agar mendapatkan hasil yang optimal. Namun kurangnya arahan dan 
pendampingan, prasarana transportasi serta komunikasi masih kurang mendukung sehingga pemberdayaan ini belum cukup mendapatkan hasil yang maksimal. Program ini merajuk pada pendapat (Najiyati, S., dkk., 2005) tentang prinsip pemberdayaan salah satunya yaitu partisipatif yang artinya program pemberdayaan yang sifatnya direncanakan, dilaksanakan, diawasi, dan dievaluasi namun perlu proses pendampingan yang melibatkan pendamping yang berkomitmen tinggi terhadap pemberdayaan masyarakat. Selain sarana dan prasana yang harus didukung oleh desa infrastruktur lainya juga harus diperhatikan dengan baik sehingga pemberdayaan yang diharapkan dapat terwujud.

\section{KESIMPULAN}

Berdasarkan hasil penelitian tentang pemberdayaan masyarakat pesisir dalam upaya meningkatkan ekonomi dan kesadaran administrasi di Dusun Pondok Mimbo, Desa Sumberanyar, Kecamatan Banyuputih pandangan dari masyarakat yang diberdayakan sangat setuju tentang adanya program pemberdayaan yang dilaksanakan desa. Masyarakat pesisir sangat mendukung dengan adanya program - program pemberdayaan tersebut, masyarakat pesisisr dapat memanfaatkan sumber daya alam serta menggali potensi sumber daya manusia yang mereka miliki. Pemberdayaan ini juga diharapkan dapat mencapai tujuan untuk meningkatkan ekonomi masyarakat yang diberdayakan. Namun kurangnya arahan serta motivasi dan pendampingan yang signifikan maka program pemberdayaan yang terlaksana belum mecapai tujuan yang diinginkan.

\section{DAFTAR PUSTAKA}

Durianto, R. (2014). Pemberdayaan Masyarakat Nelayan Melalui Klinik IPTEK Mina Bisnis (Studi di Dinas Kelautan dan Perikanan Kabupaten Lamongan dan di Desa Weru Kecamatan Paciran Kabupaten Lamongan). Jurnal Administrasi Publik, 3(1): 22-28.

Ma'arif, R., \& Nugroho, T. (2016). Pemberdayaan masyarakat nelayan melalui pengembangan perikanan tangkap di Desa Majakerta, Indramayu, Jawa Barat. Agrokreatif: Jurnal Ilmiah Pengabdian kepada Masyarakat, 2(1): 17-24.

Mulyatun,M. (2019). Pemberdayaan Masyarakat Pesisir Berbasis Potensi Lokal; Alternatif Ketahanan Pangan Berupa Tepung Magrove. Dimas: Jurnal Pemikiran Agama untuk Pemberdayaan, 18(2): 211-238.

Rahim, M., Tahir, M., \& Rumbia, W. A. (2014). Model Pemberdayaan Masyarakat di Wilayah Pesisir dalam Menanggulangi Kemiskinan di Kabupaten Buton, Sulawesi Tenggara. The Winners, 15(1): 23-33.

Rahmanto, D., \& Purwaningsih, E. (2016). Pemberdayaan masyarakat pesisir Pulau untungjawa dalam upaya meningkatkan kesadaran hukum dan kemandirian nelayan. ADIL: Jurnal Hukum, 7(1): 111-125. 
Rosyidi, S. (2009). Pengantar Teori Ekonomi. Jakarta: Raja Grafindo Persada. Suharto, E. (2017). Membangun Masyarakat Memberdayakan Rakyat. Bandung: PT Refika Aditama.

Tampubolon, D. (2012). Strategi pemberdayaan masyarakat pesisir di Kabupaten Kepulauan Meranti. Sorot, 8(2): 153161.

Theresia, A. (2015). Pembangunan Berbasis Masyarakat. Bandung: Alfabeta.

Tinambunan, H. S. R. (2016). Pemberdayaan masyarakat desa pesisir melalui penguatan budaya maritim dalam menghadapi pasar bebas masyarakat ekonomi ASEAN. Fiat Justisia Journal of Law, 10(1):15-33.

Witarsa, W. (2015). Model pengembangan ekonomi masyarakat pesisir berbasis co-management sumberdaya perikanan di Kabupaten Pontianak. Jurnal Economia, 11(1): 26-46. 